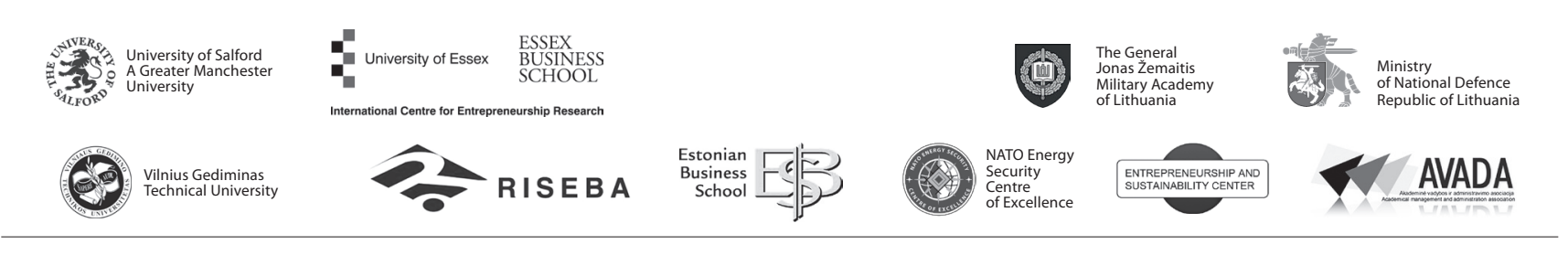

\author{
JOURNAL OF SECURITY AND SUSTAINABILITY ISSUES \\ ISSN 2029-7017 print/ISSN 2029-7025 online \\ 2017 December Volume 7 Number 2 \\ https://doi.org/10.9770/jssi.2017.7.2(4)
}

\title{
SOCIAL ECONOMY AS A TOOL TO ENSURE NATIONAL SECURITY
}

\author{
Vladimir Menshikov $^{1}$, Olga Volkova ${ }^{2}$, Nataliia Stukalo $^{3}$, Anastasiia Simakhova ${ }^{4}$ \\ 1,2 Daugavpils University, Parades Str. 1, Daugavpils, LV-5401, Latvia \\ ${ }^{3,4}$ Oles Honchar Dnipro National University, Dnipro, Ukraine \\ E-mails: ${ }^{1}$ vladimirs.mensikovs@du.lv, ${ }^{2}$ olga.volkov@du.lv, ${ }^{3}$ nstukalo@ukr.net; ${ }^{4}$ simakhova_a@fme.dnulive.dp.ua
}

Received 21 February 2017; accepted 15 September 2017

\begin{abstract}
The article sums up some results of the studies devoted to the socialization of the economy in the aspect of the reduction of threats to national security. The following research objectives were defined by the authors: an attempt to estimate the role of such functions of social economy as concern for public health, reduction of social and economic inequality, increase of social cohesion and trust that is most fully reflected in the phenomenon of social capital. A special place is given to the assessment of the manifested implementation of socialization of economy on the examples of Latvia and Ukraine. As arguments, the authors use both their own empirical studies and the data of national and international analytical and statistical institutions. The carried out analysis provides a clearer vision of the model of strengthening the socialization of economy in the aspect of ensuring national security with emphasis on economic security. Weak realization of the socialization of economy inevitably leads to an increase in social-economic inequality of population, when along with economic inequality other components of aggregate capital can serve the main catalyst for this negative process. For different countries at different times these components of aggregate capital are very specific. In some cases, the dominant threat is health capital, in others the human (vocational and educational) capital. The proposed model reflects both the theory of aggregate capital as a methodology for analysis of the interconnection between social economy and security and the role of social capital as an important indicator of inequality, and, at the same time, the most important indicator of stability and security.
\end{abstract}

Keywords: social economy, security, inequality, aggregate capital, health capital, social capital

Reference to this paper should be made as follows: Menshikov, V.; Volkova, O.; Stukalo, N.; Simakhova, A. 2017. Social economy as a tool to ensure national security, Journal of Security and Sustainability Issues 7(2): 211-231. https://doi.org/10.9770/jssi.2017.7.2(4).

JEL Codes: O15; P36; I14; I38

\section{Introduction}

The sustainable development of national state in all social spheres is the main guarantor of ensuring the security of society, state and individual. Thus, the concept of security of Latvia emphasizes that national security can be achieved by ensuring political, social and economic stability, by developing effective military structures, by creating a civil defence system for crisis management, by constitutional developing on the basis of legislative and executive structures in accordance with international agreements and laws, and by integrating into European and transatlantic political, economic, security and defence structures.

There is no one single-valued definition of security. At different times, many authors bring their own, substantiated by the interpretation of the objective reality, definitions (Tumalavičius, 2017):

Jozsef Balazs: "International security is determined basically by the internal and external security of the various social systems, by the extent, in general, to which system identity depends on external circumstances. Experts generally define social security as internal security. Its essential function is to ensure the political economic 
power of a given ruling class, or the survival of the social system and an adequate degree of public security." (Runcis 1999).

Penelope Hartland-Thunberg: "National security is the ability of a nation to pursue successfully its national interests, as it sees them, anyplace in the world." (Runcis 1999).

National Defence College (Canada): "National security is the preservation of a way of life acceptable to the ... people and compatible with the needs and legitimate aspirations of others. It includes freedom from military attack or coercion, freedom from international subversion and freedom from the erosion of the political, economic and social values which are essential and potential adversaries." (Runcis 1999).

Richard Ullman: "A threat to national security is an action or sequence of events that 1) threatens drastically and over a relatively brief span of time to degrade the quality of life for the inhabitants of a state, or 2) threatens significantly to narrow the range of policy choices available to the government of a state or to private, nongovernmental entities (persons, groups, corporations) within the state.” (Runcis 1999).

Arnold Wolfers: "Security, in any objective sense, measures the absence of threats to acquired values, in a subjective sense, the absence of fear that such values will be attacked." (Runcis 1999).

In this regard, security concerns are becoming more topical. According to the Scopus database, in the last 15 years (2001-2016) a number of articles in social sciences that contain key word "security" (safety, security) has increased significantly from 2.296 to 12.239 publications (Elsevier 2017).

The issues of security attract researchers from Latvia and Ukraine as well. The United Nations Development Programme Latvia Survey on Human Security 2002 contained a lot of interesting facts and innovative approaches (the team of its authors received the UNDP award in the nomination "Innovations"). According to a sociological survey carried out in the framework of this study, out of 32 threats to their lives the respondents most often indicated threats related to health, largely outpacing other threats to their own security (UNDP Latvia 2003). Later, Latvian researchers used their experience while studying more specific security issues: sociological aspects of security (Men̦šikovs 2004, Meņšikovs 2005), political aspects of security (Ozoliņa 2012), linguistic aspects of public security (Ozolina 2016); researchers of other countries pay great attention to energy, environmental, military security and legal aspects of security (Raudeliūniené, Tvaronavičienė, Dzemyda 2014, Lankauskienè, Tvaronavičienė 2012, Gasparėnienė et al. 2016; Tumalavičius et.al. 2017; Panfiluk, Szymańska 2017; Dirzytè et al. 2017).

Recent studies in Latvia have shown that the population of the country still sees range of issues related to health as its main threat. According to the Eurobarometer, in 2017, health issues are the most topical in the estimates of the Latvian population. 36 percent of the interviewed inhabitants of Latvia reported their concerns on the issues connected with health and social protection, and, in the European Union, in general, this indicator makes only 20\% (European Commission May 2017). Viktors Avotinšs, well-known Latvian writer and journalist, recently stated: "I believe that it's time to give a clear and convex legal and moral assessment to our internal relations. The state security will only benefit. Because then you can hope that politics will stop splitting the society and begin to unite it" (Avotiņš 2017).

In Ukraine, attention is also paid to research on security issues, and, first of all, on the ones on economic security (Geyets et al., 2006, Predborskiy, 2005). N. Ringach, Ukrainian researcher, singles out public health as a factor of the national security of Ukraine and justifies the theoretical and methodological basis for improving public administration in the field of health care (Ringach 2009).

It would seem that family doctors in Latvia, who began an indefinite strike in the summer of 2017, rightly demand the authorities to pay more attention to public health issues. However, there is a question here - will the increase of the salaries paid to the doctors solve the range of the issues connected with the health of the 
population, its healthy way of life? It was only in the Middle Ages, when each guild took care of its members, as a phenomenon of social state had never been put forward by anybody.

It is obvious that there is a lack of a broader view of the issues of security, public health, social economy, inequality, social capital, which should be considered together with respect to a specific time and a specific place with the aim of finding both a dominant threat to national security and the main means of overcoming the accumulated threats.

The proposed analysis of the security issues of Latvia and Ukraine is an attempt to give a more systematic consideration of these problems, especially emphasizing the role of social and socio-economic aspects.

\section{Social economy and economic security}

Security is a multi-faceted concept that attracts attention of the representatives of almost all social sciences. The fundamental basis of the study of economic security was laid in the 80 s of the $20^{\text {th }}$ century, when, in 1984-1985, an expert group was created on behalf of the UN Secretary-General, who developed "security concept" (Rozanov 1994). Experts concluded that security should be considered as an all-encompassing concept that reflects the growing interdependence of political, military, economic, social and technical factors. This was inherently a certain innovation, since security had always been perceived as a military-political concept.

Later, scientists began to consider security from the point of view of various aspects. Latvian researchers focused their analysis of security on a personal perception of security in seven aspects: economic, personal, health, environmental, food, community, political security (UNDP Latvia 2003). The essence of the concept "security" and the measurement of security activities were put forward by V.A. Pedborskiy, Ukrainian scientist (Pedborskiy 2005). The author claims that security is a result of a certain conscious social activity to ensure the security of individual, family, society, and state.

It can be argued that the concept "security" is sufficiently general and collective, and it can be used in relation to many spheres of society. The subject of our study is primarily economic security and its relation with the state of social economy, socio-economic inequality.

The approaches addressing the essence of the category "economic security" can be divided into several groups, namely:

1. Economic security as a set of conditions that protect the economy from internal and external threats (Cormac 2014, Holikov 2014) and provide decent living and personal development, socio-economic stability and political, and military potential of society (Valeriu, Diamescu 2010). In this case, economic security helps to protect the country's vital interests and realize social capital.

2. Economic security is the ability of individuals, households or communities to meet their basic needs constantly and at a decent level (ICRC 2017). The definition provided by the International Committee of the Red Cross considers economic security from the social point of view connected with provision of food, shelter, clothing and hygiene, as well as expenses related to health and education. The above provided interpretation reflects the impact of economic security on the provision of sustainable development and the functioning of social economy.

3. Economic security is a state of economy, when sustained economic growth, sufficient satisfaction of social needs, effective governance, protection of economic interests at the national and international levels are ensured (Arhipov 1994). Also, to ensure economic interests, it is important to ensure financial stability and efficiency in the country (Stukalo 2006).

4. Economic security is a state of economy, society and state power institutions, which ensures the implementation and guaranteed protection of national economic interests, progressive social and economic development of the country, and sufficient defence potential even in unfavourable internal and external processes (Geyets 2006). In this context, the relationship between security and national interests is traced.

5. In the context of globalization, economic security ceases to be an internal issue of states, but becomes a 
factor of international stability, geopolitical cooperation. The economic security of countries can be achieved only in the context of regional and global integration (Andruseac 2015). This is natural, because, in the global world, integration processes penetrate into all spheres of society, not only in the economic sector but also in the social one (Simakhova 2016); this requires an effective concept of national security in the context of globalization.

Based on the above provided analysis, it can be summed up that economic security is a state of protection of national interests against external and internal threats in all spheres of society, which ensures the country's independence, stability and development. Moreover, there is a correlation and consistency of the definitions of "security", "economic security", "national interests" in accordance with their content and logical connection. This creates a constructive theoretical and methodological basis for identifying and implementing measures to overcome threats in the economic, social and other spheres of society, which will ensure stability and development of the country.

Undoubtedly, the effective functioning of social economy affects the provision of economic security. Moreover, conversely, without economic security it is impossible to provide a decent standard of living for the population. Economic security is closely related to the functioning of social economy (see Figure 1).

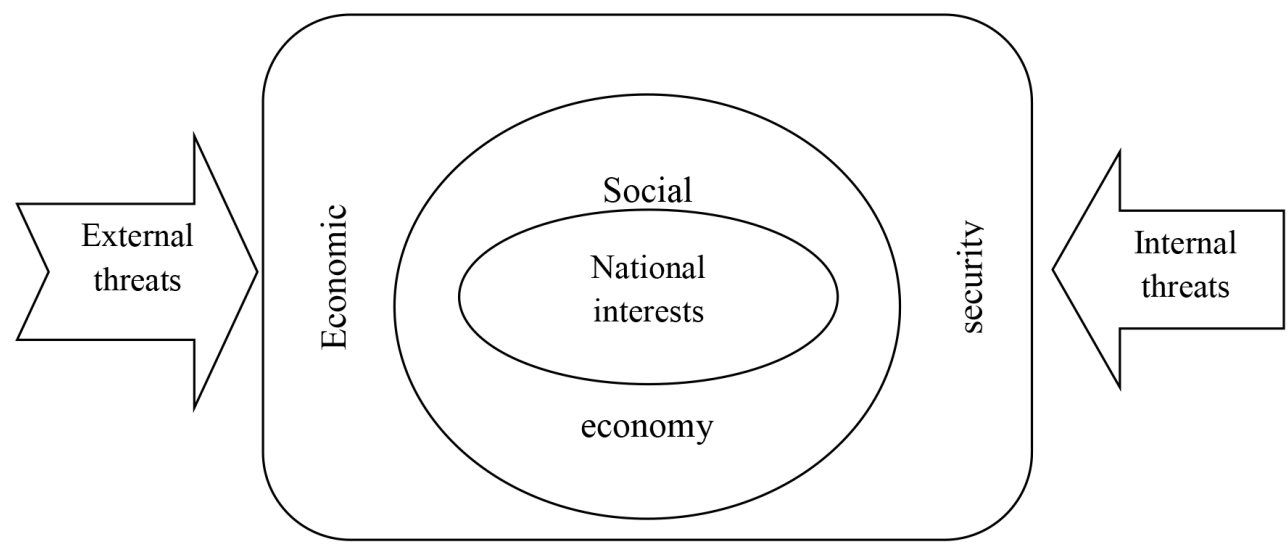

Figure 1. System of national security

Source: author's own work

A definite link between social economy and economic security can be traced in the works of the founders of the theory of social economy. In 1946, A. Müller-Armak, German scientist, introduced a concept of "social market economy" in his work "Economy Regulation and Market Economy" (Müller-Armack 1946). The scientist stressed that economic freedom, which should not be limited to anything, and market mechanism have the greatest importance for social economy. The scientist saw security of economic freedom in relation to state, entrepreneurs and employees only in social market economy. Thus, only social economy based on the principle of social justice can guarantee the implementation of the best opportunities for comprehensive economic growth and economic security of the country. It is with this understanding that not only low-income segments of the population, who are provided with various kinds of benefits and assistances, demonstrate their interest, but also these are rich citizens, for whom the issue related to the provision of security and the realization of social capital is important.

The need for the development of social economy is conditioned by the set of global problems that humanity faces daily - demographic, economic, military, environmental, social, etc., which, by all means, are focused on the provision of human security issues related to the population. Moreover, social economy narrows the gap between the rich and the poor, and also contributes to the stability and sustainable development of one specific economy and the entire world community. 
In 2001, it seemed to us that it was not possible to expect great success in the next 10-15 years in the transformation of former socialist countries into a social state: "Poverty and unemployment, on the one hand, the weakness of official socio-political institutions on the other, activate and strengthen the patron-client relations, which serve as the backbone of post-communist sociality. In our conditions, the growing ties of patrimonial domination and protection are probably the most easily realized option to meet the natural needs of people in a sustainable and secure social environment.

In post-communist societies, the growth of the features of the New Middle Ages (in other words - quasifeudalism, electronic feudalism) has a very contradictory effect on man, on his relations with the state, on the direction and speed of the dynamics of social processes. Undoubtedly, one can attribute the increase in the space of freedom for an individual personality (almost total dependence on all parameters from the state has been substituted by a new dependence on one or another master based on one's own choice) to the positive consequences" (Menshikov 2002). Social economy has an important role in the expansion of the space of freedom and the assertion of a new sociality.

At the present stage, the role and significance of social economy can be traced in the list of its main functions, which are:

1. social reorientation of production;

2. reduction of social differentiation and inequality of population;

3. development of the middle class as the basis of social economy;

4. humanization of labour and life of population;

5. increase of the importance of social sphere;

6. provision of quality education and medicine;

7. promotion of implementation of social capital;

8. provision of stable development of society, as well as universal security.

In addition, in the centre of social economy, there is an individual person with his various needs and potential opportunities. It is social economy that responds to social needs, and helps to realize the potential of every individual person. Providing stability and security, social economy carries out its tasks.

Alfred Müller-Armak, scientist, investigating social economy, substantiated the key goal of social market economy, namely: on the basis of a competitive market system, to link free initiative with social progress that will be provided by the results of market-economic activity (Müller-Armack 1966). It is very important for us to emphasize that the fruits of social economy bring tangible benefits to all social and economic groups of society. Therefore, if the poor are primarily interested in benefits and social assistance, then for the rich the aspect of security and social progress is significant. In our opinion, this is extremely important, since social economy is by no means reduced to the provision of social payments and standards, because in this case a person will not have incentives to realize his own potential (Stukalo 2017). Social economy is associated with personal economic freedom and responsibility that are based on universal security.

Therefore, the sphere of social economy actually acts as the main field of human development in society. Taking into account the theoretical aspects and practical forms of "social economy", it can be asserted that this term contains a broad methodological toolkit that is implemented at all managerial levels; it is mainly identified with the forms and conditions of ensuring the economic capacity of the subject of economy to realize his potential at a decent level (Sardak 2017). Hence, freedom, regulation, competition, security from internal and external threats are important both for social economy and for economic security. This feature corresponds to the fact that the functioning of social economy (as well as ensuring national security) takes place in the market environment in both developed and post-communist countries with transitive economies.

In post-communist countries, the specific feature of the development of social economy is marked by the fact that the transformative period is associated with certain problems such as a low share of budgetary social expenditures, low incomes of the population, and a high level of bureaucracy. Nevertheless, the positive point 
is that these countries have a high indicator of human development. In this statement, we rely on the statistics of the Human Development Report, when, in 2016, the level of the HDI for Slovenia was 0.890, the Czech Republic -0.878 , Estonia -0.865 , Poland -0.885 , Lithuania -0.848 , Slovakia -0.845 , Hungary -0.836 , Latvia -0.830 , Croatia -0.827 , Russia -0.804 , Romania -0.802 : these are countries with a very high level of human development. Belarus (0.796), Ukraine (0.743) and almost all the remaining post-communist countries belong to the group of the countries with a high level of human development (UNDP 2016). This shows that the former socialist countries retain their educational and human resources potential.

At the global level, one of the tasks of social economy is a solution of the problem of poverty. D. Restakis, scientist, considers social economy as a means of eliminating disproportion in the income of the population by placing social and humanitarian problems at the centre of the economy (Restakis 2007). In this regard, the affordability of health care and a healthy lifestyle for all sectors of society is increasingly important. Here it is possible to trace an important task of economic security - the elimination of high disproportions in the incomes of the population and the reduction of social inequality.

\section{Health capital as the most important indicator of the sociality of economy}

In 1979, the UN General Assembly adopted a resolution according to which human energy received through the improvement of health should be directed at the promotion of economic and social development of society, and this development, in turn, should be used to improve health (UN General ... 1979). The resolution documented the exceptional importance of public health as the only criterion of expediency and effectiveness of the spheres of economic management. The efficiency lies in the potential social and economic benefits that can be obtained only when an activity is carried out taking into account its influence on human health.

Health issues are given considerable attention by various state and public structures. For instance, the implementation of the European health policy "Health 2020 " is an important contribution to strengthening the nation's health potential. Reduction of economic losses through the restoration of labour potential and reduction of financial expenses on pension payments for disability and temporary disability benefits are one of the longterm socio-economic consequences of the given policy, if it is successfully implemented.

The economic aspects of health, its impact on the resulting economic indicators are presented in a variety of theoretical models since the middle of the $17^{\text {th }}$ century. A representative of the classical economic school, William Petty, English physician, considered health as a multi-resource factor of economic development. In his work "Word to the Wise" (Verbum Sapienti, 1664), he estimated the profitability of healthy employees and brought about an objective relationship between the deaths of people from epidemics and the losses of the state, between the costs of preventing diseases and losses resulting from the spread of the latter. W. Petty believed that only labour could be the only source of wealth - "the good of the country should be sought in the productive power of the man himself" (Petty 1899).

In the $50 \mathrm{~s}$ of the $20^{\text {th }}$ century, Health Economics was separated as a science that studies the interaction of healthcare with national economy, the formation, distribution and use of material, labour and financial resources in public health; it considers public and individual health as one of the components of economic growth, and, therefore, sustainable development of the state (Wagstaffetal, 2012). Health protection started to be treated as a profitable, economically expedient branch of investment funds.

To estimate the economic costs of death, a number of prominent economists, as well as international financial organizations (the World Bank, the International Monetary Fund) began to use a broader concept than GDP per capita. Their approach is based on an undeniable fact that GDP is an imperfect tool for assessing social welfare, since it does not take into account the values of health. In 1972, in connection with the analysis of gross national product and the quality of life US, professors W. Nordhaus and J. Tobin introduced an indicator, which they called "Index of Economic Welfare". P. Samuelson renamed it "Net Economic Welfare" - a macroeconomic indicator that takes into account the change of public welfare under the influence of factors not reflected in the 
GDP indicator. In the existing theories of public welfare, economists distinguish its various content aspects: aggregate benefits (utilitarianism); usefulness of a set of benefits (welfare economics); living conditions (theory of quality of life); money income (concept of resources); subjective perception of well-being (behavioural approach). Many experts admit that Net Economic Welfare is the most suitable economic indicator of public health (Nelson 2009).

The broad interpretation of national welfare and capital goes back to the ideas of I. Fisher, who suggested that everything that meets the following criterion should be considered capital: generating an income stream for a certain time, where any income is viewed as a product of some kind of capital (Fisher 1906). From this point of view, capital is any stock of goods that can be accumulated and used for a sufficiently long period of time, generating income.

The Theory of Human Capital as an achievement of economic thought is a result of a thousand-year evolution of the views of researchers on the key unit of human capital - the development of human capabilities for work. In modern conditions, human capital can be considered as the main factor of economic development. This is evidenced, in particular, by the Human Development Index (UNDP 2016), which is higher in more developed countries. In the economic literature, human capital is usually understood as comprising the health, knowledge, skills, competence of an individual that contribute to the production aimed at higher wages.

Different researchers consider health is an integral part of various types of capital (human, physical, physiological, vital, biophysical, etc.). M. Grossman, American economist, was the first one to single out "health capital" as an independent category. He believed that health capital and human capital should be treated separately. In his article published in 1972, M. Grossman considers health capital as an asset that allows its owner to use his human capital for "intended purpose" as long as possible, i.e., it is an aggregate number of time a person can spend earning money and producing goods (Grossman 1972). M. Grossman believes that health can be considered as a certain stock or durable consumption goods (health stock), which is necessary for the production of human capital. Health reduces a number of sick days and, accordingly, increases a number of days of engagement in any kind of activity, both market and non-market. Investments in health capital are considered from the point of view of individual rational choice. Knowledge stock possessed by a person affects his market and non-market productivity, while his health stock determines the aggregate number of time he can spend earning money and producing goods. This stock is health capital.

In M. Grossman's model of demand for health, a change in health stock is connected with investments in health and the rate of decline in health stock, which grows with age. The model demonstrates the relationship of individual investments in health with the increase in life expectancy and effective performance. The increase in life expectancy means an addition of additional periods of activity, during which an individual receives income and invests his capital as well. The health capital model served as a model of "a workhorse" in health economics and contributed significantly to the understanding of a wide range of phenomena of health and healthcare (Galama 2013).

The attitude to health as to investment goods is expressed in the desire of individuals to improve the quality of their life not only at the present moment, but also in the future by creating a continuous stream of benefits that ensures the realization of the abilities of a person and corresponds to the person's needs.

In general, health capital is understood as a combination of such characteristic features as physical strength, endurance, working capacity, immunity to diseases, an increase in the duration of active working life. Usually, in the context of the development of health capital, they consider the formation of an effective healthcare system, which is mentioned among the most important conditions for the preservation and development of human capital (Chernova 2008). The provision of the conditions for preserving and increasing the health capital of population is a multifactorial problem that lies in different fields of research and practical implementation. 
As a rule, the researchers of the Institute of Social Investigations at Daugavpils University apply the theory of aggregate capital of an individual or a social group, where physical capital is also present. We consider a systemic vision of the phenomenon of the aggregate capital of a social subject, as well as the possibility of its empirical research, which has already been successfully tested in a number of our scientific projects, the advantage of our approach. In particular, health is one of the components (indicators) of the physical capital of a person (a group), where there are also such elements as "ability to withstand stress and psychological problems" and "beauty, external attractiveness" (Menshikov, Vanags, Volkova 2013).

Due to the lack of a generally accepted concept and universal methods for studying health capital, there are various problems in measuring it.

First of all, it should be noted that there is no global index of "health capital", which can give the most complete information and trace the dynamics of changes in the level of public health, its health literacy and health-saving behaviour, habitat, and the effectiveness of the public health system. Health indicators are included into many global indices, such as the Quality of Life Index, the Human Development Index, the Life Expectancy Index, the Genuine Progress Indicator, the OECD Better Life Index, the Legatum Prosperity Index and many others. However, in the opinion of the authors of the article, in order to assess health capital of population, these indices are an imperfect tool, since they have a limited number of health indicators (in many global indices, health is assessed only by one indicator - life expectancy at birth). Many indices are not calculated on a regular basis, which excludes a possibility to trace their tendency. The geographical scope of many global health-related indices is also limited. A number of indices counted in the European countries cannot be used for comparison of some countries in Eastern Europe and CIS countries.

Having carried out a comparative analysis of global indices, including the ones for the analysis of health capital in the context of security in different countries, the authors decided that it would be more appropriate to use the sub-indices of the Prosperity Index. The Legatum Prosperity Index is a composite indicator presented by British Analytical Centre "The Legatum Institute", which measures the achievements of the countries of the world in terms of their prosperity. The index is based on many different indicators, combined in nine categories, which reflect different aspects of society and parameters of public welfare: economy, entrepreneurship, governance, education, health, security, personal freedoms, social capital, and ecology. In 2016, Luxembourg (84.92), Singapore (84.39), Switzerland (83.91) had the highest value of the Health sub-index (Legatum Institute Foundation 2017); in accordance to this index Lithuania was ranked 80 $0^{\text {th }}$ among the countries (70.95), Latvia $-82^{\text {nd }}(70.95)$, Ukraine $-111^{\text {th }}(63.02)$ among 149 countries. In the cases, when only life expectancy is taken into account, the data diverge. This is connected with the fact that the indicators of the Prosperity Index affect the most important spheres of public life (the quality of economy, governance, social capital, etc.), which significantly affect the health of the population.

Health capital is the most significant factor in the productivity of economic activity. If the physical and spiritual health of the nation is at a low level, it is impossible to expect the formation and implementation of any programmes to strengthen the country's security.

As it is noted in the World Development Report 2006, "Social Justice and Development", along with the inherent importance of health as an aspect of well-being, poor health can directly affect a person's opportunities wages, school performance, ability to take care of children, participation in public activities, and etc. (The World Bank 2005). This significant instrumental function of health suggests that inequalities in health often lead to inequality in other dimensions of well-being.

The majority of rich countries have a universal health system that provides quality care for all their citizens at almost no cost. Despite this, life expectancy tends to vary according to income among individuals; perhaps it happens because additional income allows for better care or helps to reduce stress, to have a better diet and a higher workload. 
Social and economic conditions (social determinants) significantly influence the health of people throughout their lives. A significant amount of research in several disciplines was devoted to documenting and explaining the significant disproportions in the sphere of health among social and economic groups. Modern literature concentrates on the evaluation of cause-effect consequences. It is found out that causality is observed in both directions: it is proved that health affects social and economic characteristics, such as employment and income, and that social and economic characteristics, in particular education, affect health. For people with low incomes the probability of serious illness and premature death is at least twice higher than for people with high incomes. Moreover, social differences in health, which can also be called a social gradient of health, are observed at all levels of social ladder, not being limited only to the category of the poor (Dahlgren, Whitehead 2007). The most important conditions for developing an effective social and economic policy are the following: a complete and adequate view of how inequality is formed (whether it is income or health inequality), what factors influence this process, how these types of inequalities are linked, how to reduce inequalities to socially acceptable levels.

The identification of the mechanisms, by which specific socio-economic indicators (such as education, income and wealth, and health) interact with each other, are vital to assess the normative case for reducing health inequalities and developing strategies that are effective for this (Deaton 2002).

There are three main theoretical positions on why income inequality can adversely affect the health of population. First, the marginal utility of income in improving health declines with income growth (Hall, Jones 2007). Life expectancy grows with income, but moving up the income ladder, the degree of improvement for an additional unit of income decreases. Thus, taking some money from a poor person and giving it to a rich person should increase the life span of a rich person, reducing the life expectancy of a poor person.

The second conceptual approach is that large disparities in incomes in a society increase stress. Richard Wilkinson and Kate Pickett believe that "greater inequality seems to heighten people's social evaluation anxieties by increasing the importance of social status ..." (Wilkinson, Pickett 2009). Socio-economic (including income) inequalities form unequal opportunities for adaptation; ability to cope with physical and emotional stress, chronic stresses can lead to a change in the neuroendocrine and psychological functioning of a body and increase the risk of diseases.

Government policy is the third position of the cause-effect relationship between health and inequality. Greater income inequality can lead to an increase of the opposition of the rich against higher taxes, which hinders the expansion of public health coverage or the widespread introduction of new medical technologies (Clarkwest 2008). In this respect, the number of provided health services and their quality is reduced.

The development of modern economy has contributed to the emergence of a new treatment of health, considering it as a specific public good, inequality in access to which cannot be considered socially acceptable. This treatment is reflected in the World Health Organization's ambitious programme "Health for All", which calls for a reduction of inequalities in health between countries and within countries by twenty-five percent by the beginning of the 21 st century. According to the WHO documents, the public health policy is based on the conceptualization of health as a specific public good, access to which should be determined in accordance with the principles of social justice (World Health Organization 1990). It is about equal opportunities in providing key health resources for the representatives of different social status groups of the population.

In Latvia, the public health policy related to the issue of health and social protection tops the list of population's concerns. In Lithuania and Latvia, expenditures on social protection as a percentage of GDP are the lowest in the European Union. According to the Eurostat data, in 2011, expenditures on social protection in Lithuania were $11.1 \%$ of the GDP, in Latvia - $11.5 \%$, in Estonia - 17.1\%. In its turn, Finland had a high level of social expenditures, where $25.6 \%$ of the GDP was spent for these needs, France - 24.6\%, Denmark - 23.6\% (European Commission 2017 (2)). As neuroscientist Valdis Keris, chairman of the Latvian Health and Social Care Workers' Trade Union, stated in his recent interview, "according to the statistics, every day in Latvia 17 people (6.5 thousand people per year) die due to a shortage of health financing (Slyusareva 2017). 
It can be argued that inequality in health is a sign of a low measure of the sociality of economy, the result of an erroneous or ineffective social policy of state, a consequence of the retarding role of socioeconomic stratification of society, in which there is no concern for the preservation and growth of the middle class. As Paul Krugman, Nobel Prize winner in Economics, noted, "the guarantee to get medical care is one of the key signs of genuine belonging to the middle class" (Krugman 2007).

\section{The world trend of the dynamics of inequality - "hollowing out" (lack of positive dynamics) of the middle class}

The existent global stratification of the humanity, strengthening of the role of "super-class", when the wealth and power of its representatives exceeds the national income of some countries, is increasingly visible. On the eve of the Economic Forum in Davos (2017), Oxfam (British charity organization) reported a shocking fact: the aggregate capital of 8 richest people in the world makes up $\$ 426$ billion. The poorest half of humanity, about 3.6 billion people, owns the same wealth. The crisis that hit the global economy made the richest people in the world even richer. According to the estimations of the authors of the report, in 2009-2016 the aggregate capital of 793 richest people in the world was growing by $11 \%$ annually, having increased from $\$ 2.4$ trillion to 5 trillion. The Oxfam experts predict that, if the growth rates remain the same, then in the next 25 years there can appear the first trillionaire on Earth (Oxfam 2017).

The etacratic stratification of the Soviet society collapsed and broke up almost 25 years ago, but such a social stratification, which would be in compliance with all the principles and demands of the market economy, political democracy, social and spiritual progress, has not been formed yet. At present, we have a set of social groups that are difficult to differentiate: classification criteria for these groups are varied and unstable, and the mobility of some individuals is similar to Brownian motion featured by a tendency to maintain the existing status, which is perceived by the participants of "the race" as a running on the spot. In modern conditions, when there is no prohibition to use the terms "stratification" and "class" while analyzing our existing society, the articles and research materials of our sociologists, which do not contain these terms, seem to be strange. This is true for the latest edition of "Latvia. Human Development Report", prepared with the participation of Latvian sociologists and even containing a section on social inequality (Bela 2014).

The main attention is paid to poverty: "In Latvia, the level of both relative poverty and absolute poverty is very high, the situation is even worse only in Bulgaria and Romania. In the EU, the poverty level is calculated taking into account three indicators of social inclusion: the level of poverty risk, the number of people living in deep social deprivation and the number of people in households, where there is no one engaged in paid employment. In Latvia, $40 \%$ of the population are at least in one of the three previously mentioned poverty groups, which is a very high rate" (Bela 2014). It is possible to agree with the idea of the authors of the study that there is a need to correct the social security system in the direction of reducing the reproduction of a high level of social inequality, but it does not touch upon the question of how to increase the proportion of the population of working age, who practically do not need help from such a system.

The amount of income of the population and the degree of their differentiation are the basis for assessing the dynamics of the population inequality. The distribution of the population by income provides important information for assessing the extent of its stratification and inequality. However, it is quite difficult to compare information in this form, so scientists and economists often use the Gini coefficient (income concentration index) as an indicator of differentiation. The Human Development Report (UNDP 2016) gives the value of the Gini coefficient for countries on a scale from 0 to 100 , where 0 is absolute equality. Table 1 shows the data for a group of the countries of special interest to us. 
Table 1. Gini Coefficient for Some Countries in 2010-2015

\begin{tabular}{|c|c|}
\hline Country & Gini coefficient \\
\hline Sweden & 27.3 \\
\hline Estonia & 33.2 \\
\hline Lithuania & 35.2 \\
\hline Latvia & 35.5 \\
\hline Ukraine & 24.1 \\
\hline
\end{tabular}

Source: UNDP 2016

In accordance with Gini coefficient, in Ukraine there is the lowest income differentiation among the presented countries. This is an obvious paradox, as there is a huge gap between the rich and the poor in the country. The problem is that the official statistics do not always reflect the real data, a high level of shadow economy and hidden incomes. Therefore, to get a more comprehensive picture of the stratification of society, to make a definition of the parameters of the emerging classes, especially of the middle class, sociological research is needed.

Apparently, Lloyd Warner (1898-1970), American sociologist, was the first to empirically study the stratification of American society: he singled out the middle class in it and roughly divided the US society into six social groups. One of these groups Warner called "upper-middle class", the other one - "lower middle class" (Lloyd et al.1949).

According to the majority of Western sociologists, the middle class acts as the main stabilizing force in the general balance of classes, the subject of modernization and creation of a new knowledge society, the main consumer of quality products of the modern economy, the main carrier of the life strategy of success.

Implementing the project "Aggregate Capital, Its Structure and Relation to Labour Migration" we tried to consider the issues of the formation of the middle class in our country in details. The theoretical basis of the project was a resource-based approach relied heavily on the understanding of the category of "capital" offered by P. Bourdieu (Bourdieu 1986). The use of the resource-based approach (the theory of aggregate capital) guidelines and methodology of sociological analysis - was first presented by us at an international conference in Poland (Menshikov 2008), while the test of the application of the mentioned approach to empirical sociological research was first described in an article published in the journal of Lithuanian Academy of Sciences "Philosophy. Sociology" (Menshikov 2011). The theoretical substantiation of the research project, the analysed structure of aggregate family capital, the operational notions, the main results of our analysis with respect to the issue of labour migration were published in 2013 (Mensšikovs 2013).

The aim of our additional explorations in the framework of the implemented project was to identify the main parameters of the forming class stratification that meets the needs of the society to overcome the systemic crisis and to formulate the most important problems of the society arising from the incompleteness of the process (Menshikov 2016). It was significant to pay a specific attention to the most important characteristics of the candidates for the middle class on the basis of the theory of aggregate capital.

The subject of research - the formation of class stratification in the region (estimated on the basis of cluster analysis), the main characteristics of the selected clusters on the basis of the analysis of the volume and structure of aggregate resources and aggregate capital, the role of the structure of aggregate family resources in the manifestation of the propensity of labour migration.

The hypothesis of the research: our own previous research studies and the government statistics indicate the incompleteness of the formation of class stratification that meets the needs of the society to overcome the systemic crisis, that negatively affects both the economic and social development indicators and the possibilities of the residents of the region to effectively capitalize their resources in Latvia, thus responding to their needs for the quality of life without recourse to labour migration. 
The object of the research: three age groups of the population of Latgale: 15-29-year-olds, 30-49-year-olds, 50-75-year-olds. The number of respondents - 800 people, of whom 519 people (64.9\%) living in Daugavpils. The sample is stratified by sex, age and education. Three variables are used to identify clusters:

1. household income per member per month, LVL;

2. level of education on 1-7 scale: 1 - basic, 2 - lower secondary, 3 - vocational, 4 - secondary, 5 - secondary professional, 6 - incomplete higher education, 7 - higher;

3. self-identification with a social layer on 1-6 scale: 1 - the lowest group, 2 - working class, 3 - lower middle class/upper working class, 4 - middle class 5 - upper middle class, 6 - upper class.

Table 2. Average Value of the Preliminarily Defined Variables of Cluster Analysis, Latgale, 2012

\begin{tabular}{|c|c|c|}
\hline & Cluster 1 & Cluster 2 \\
\hline Household income per member per month, LVL & 503 & 151 \\
\hline Level of education (1-7 scale) & 6 & 5 \\
\hline Self-identification with a social stratum (1-6 scale) & 4 & 3 \\
\hline Number of people in a cluster & 36 & 572 \\
\hline Share of cluster in $\%$ & 6 & 94 \\
\hline
\end{tabular}

Note: calculation of the probability of error based on the F-test ( $\mathrm{p}$ values) for all 3 variables showed that their differences between the clusters are statistically significant in all three cases, $p=0.000$.

Source: Menshikov 2016

The clustering of the population of Latgale applying the 3 variables shows only two clusters (Table 2). The first of them (Cluster 1) makes up only 6\%: average income per a family member per month made $503 \mathrm{LVL}$, level of education - incomplete higher, self-identified class - middle stratum. The majority of our respondents made up the second cluster (Cluster 2): average income of 151 LVL, level of education - secondary professional, selfidentified class - lower middle class/upper working class. Therefore it is clear why applying cluster analysis to the identified characteristics of our respondents we cannot find clusters of the upper middle class and the upper class, as it happens due to their minuscule proportion in the region and inaccessibility for sociological surveys. In turn, the absence of the lowest groups and working class, in our opinion, can be explained by a weak ability of income to differentiation. According to the formula of the Euclidean action, the variable with maximum values, dominates over the variables with minimum values (in our case, these are the levels of education and class self-identification). It can be stated that the representatives of the second cluster, first of all, group into one cluster in accordance to their family income; but their incomes, if compared with the ones of the first cluster, are relatively low and even in their entirety cannot affect the formation of groups.

Considering class stratification the way it was understood by T. Parsons, almost all members of the second cluster can be attributed to the "lower class", taking into account the complexity and inconsistency of the status positions of many of them. For example, when the income of a significant part of employees with higher education is at the subsistence level (or even below it) or when the respondent with such income identifies himself with the upper class.

The group of our respondents, who made up the first cluster marked by the dominance of self-identification with the "middle class", should be considered very carefully. First of all: has there formed a critical mass of the bearers of the selected characteristics, so that we can consider this social group a class? Secondly, how strong and stable are these characteristics even for those, who possessed them at the time of the sociological research (especially monetary income)? According to our survey, not everyone identified with the "middle class" had property and savings. 
Table 3. Aggregate Resources and Capital in Formed Class Clusters, Latgale, 2012

\begin{tabular}{|c|c|c|}
\hline & Cluster 1 & Cluster 2 \\
\hline Aggregate resource, points & 22.00 & 18.51 \\
\hline Aggregate capital, points & 19.08 & 15.15 \\
\hline Resource capitalization, \% & 86.7 & 81.8 \\
\hline
\end{tabular}

Note: calculation of the probability of error based on the F-test showed that the differences between the clusters are statistically significant in both aggregate resources $(p=0.000)$ and aggregate capital $(p=0.000)$.

Source: Menshikov 2016

Table 4. Types of Aggregate Resources and Capital in Formed Class Clusters, Latgale, 2012, \% and Rank

\begin{tabular}{|c|c|c|c|c|c|c|c|c|}
\hline \multirow{3}{*}{ Types of resources and capital } & \multicolumn{4}{|c|}{ Resources } & \multicolumn{4}{|c|}{ Resources } \\
\hline & \multicolumn{2}{|c|}{ Cluster 1} & \multicolumn{2}{|c|}{ Cluster 2} & \multicolumn{2}{|c|}{ Cluster 1} & \multicolumn{2}{|c|}{ Cluster 2} \\
\hline & $\%$ & rank & $\%$ & rank & $\%$ & rank & $\%$ & rank \\
\hline Cultural & 12.69 & 1 & 12.44 & 4 & 13.88 & 1 & 12.49 & 4 \\
\hline Economic & 12.66 & 2 & 13.06 & 2 & 13.51 & 2 & 13.46 & 1 \\
\hline Human (vocational and educational) & 12.62 & 3 & 12.30 & 5 & 12.54 & 3 & 11.99 & 5 \\
\hline Physical & 12.48 & 4 & 13.63 & 1 & 10.96 & $5-6$ & 9.81 & $6-7$ \\
\hline Social & 11.64 & 5 & 11.65 & 6 & 11.83 & 4 & 13.35 & 2 \\
\hline Symbolic & 11.43 & 6 & 10.19 & 7 & 10.96 & $5-6$ & 9.81 & $6-7$ \\
\hline Geographical & 10.77 & 7 & 12.64 & 3 & 10.60 & 7 & 13.01 & 3 \\
\hline Administrative & 9.47 & 8 & 7.66 & 8 & 9.19 & 8 & 6.89 & 8 \\
\hline Political & 6.24 & 9 & 6.32 & 9 & 4.12 & 9 & 4.48 & 9 \\
\hline
\end{tabular}

Note: The differences in most of the types of resources and capital are statistically significant, with the exception of geographical $(p=0.508)$, physical $(p=0.135)$ and symbolic $(p=0.106)$ resources and geographical $(\mathrm{p}=0.681)$ and physical $(\mathrm{p}=0.061)$ types of aggregate capital.

Source: Menshikov 2016

The analysis of the data (Tables 3 and 4) shows that the structure of the aggregate resource of the representatives of the first cluster (Cluster 1) and the one of aggregate capital are dominated by the same "powers of social improvement": cultural, economic, vocational and educational. Moreover, it is important not only to possess these identified resources, but also to be able to use them effectively, to capitalize. It is notable that the representatives of the first cluster treat social resources in a rather pragmatic way, taking into account that, in the ranking scale, social capital moves the physical one from the $4^{\text {th }}$ onto the $5^{\text {th }}-6^{\text {th }}$ one.

The inhabitants of Latgale, that form the second cluster (Cluster 2), significantly differ from the first cluster in the structure of aggregate resources and in their ability/possibility to effectively use the ones marked as available resources. Physical, economic and geographic resources dominate among the aggregate ones, whereas economic, social and geographical types of aggregate capital dominate among the aggregate capital. It is most likely to observe inability (or lack of ability at the place of residence) to capitalize one's physical resources - it is moved back from the $1^{\text {st }}$ position among the types of aggregate resources to the $6^{\text {th }}-7^{\text {th }}$ position among the types of aggregate capital. However, social resources turn out to be more significant for the representatives of the second cluster: they move from the $6^{\text {th }}$ position among the resources to the $2^{\text {nd }}$ position among some separate types of aggregate capital. Interestingly, but geographical resources are essential for the representatives of the second cluster.

Relative scarcity of vocational and educational resources and, in particular, cultural ones among the representatives of the second cluster is due in large part to their "dissent" to the hierarchy of social stratification; it does not allow a very large proportion of the population of our region really claim a place in the middle class. 
According to the self-identifications of our respondents, who entered the second cluster, economic capital dominates in the structure of aggregated capital. However, capitalization of the aggregate resources with an average in the second cluster, in monitory terms, provides the income amount, on the average, of 151 LVL per family member per month. According to the Central Statistical Office (CSO), in 2012, the income of 79\% of Latvian households was below the minimum amount needed to cover basic expenses. At that time, the required monthly income was 279 LVL and the net monthly income was 213 LVL (Rus.delfi.lv 2013). Therefore, the general situation with monetary income in Latvia differs favourably from the one in Latgale, though it qualitatively presents the economic stratification of the society, where the "middle class" is still at an early stage of its formation.

\section{Analysis of Correlation between Prosperity Index Indicators}

The Legatum Prosperity Index is an annual ranking. It is a composite indicator that measures the achievements of the countries of the world in terms of their well-being and prosperity. It has been being published by British Analytical Centre "The Legatum Institute" (a unit of the international investment Legatum group) since 2006. The purpose of the research is the study of societal well-being and its development on a global scale.

The ranking of each country is determined by calculating the weighted average of the given indicators, each of which is defined as the basis of prosperity. The indicators are based on a statistical analysis, sociological research and expert assessments of the participants of the survey. The statistics used in the ranking are taken from the United Nations, the World Bank, the Organization for Economic Co-operation and Development, the World Trade Organization, Gallup, the Economist Intelligence Unit, IDC, Pyramid Research, and other institutions. The editorial board of the Index is composed of representatives of a number of leading universities and research centers.

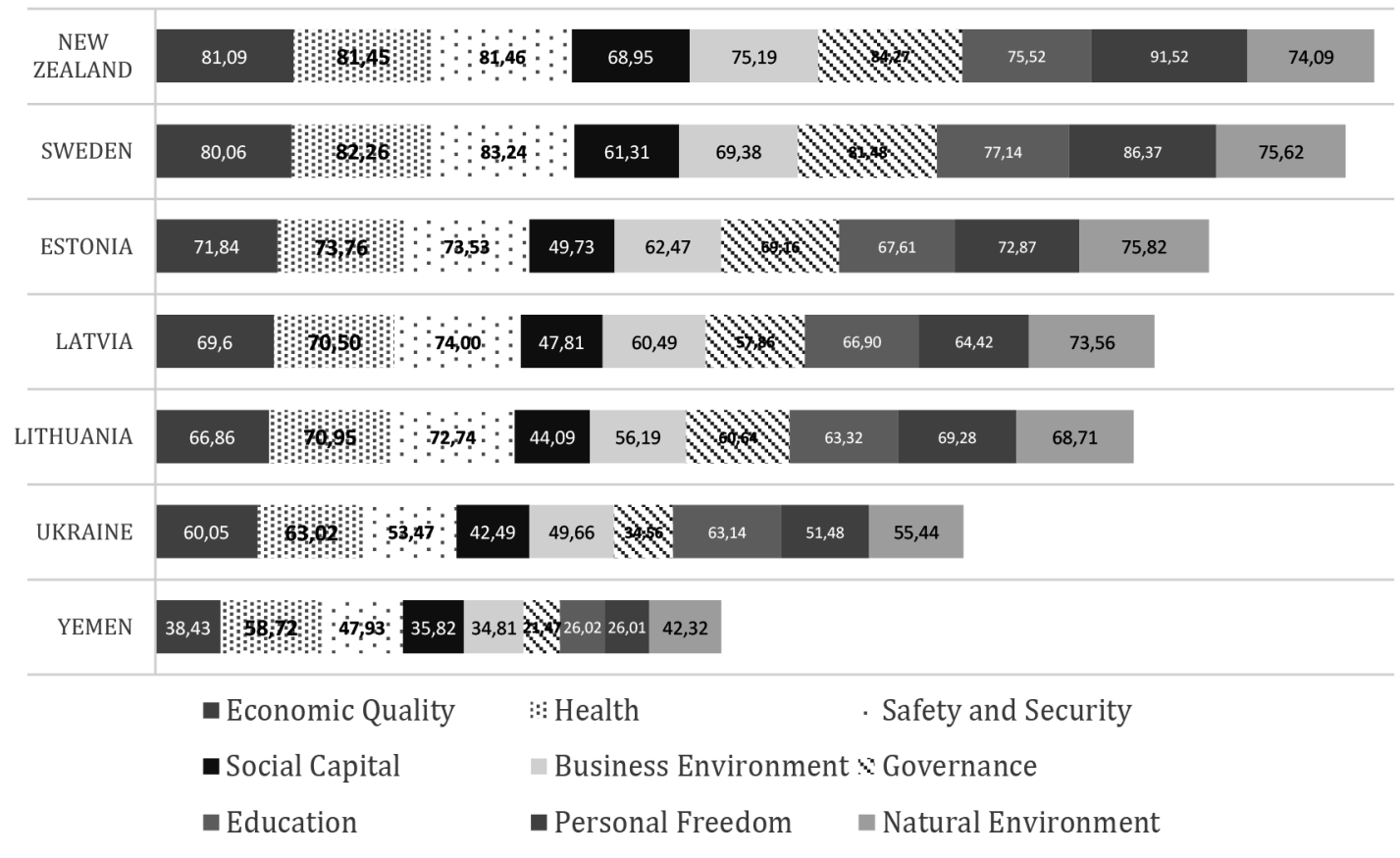

Figure 2: Sub-Indices of the Prosperity Index for a Group of Countries, Including the Ones with the Highest and the Lowest Indices

Source: compiled by the authors from the data provided by the research of the Legatum Institute (Legatum Institute Foundation 2017)

To analyse the data, the Legatum Institute uses a methodology, in accordance to which all the countries under the study are divided into quadrants (Legatum Institute 2016). 
In 2016, the countries were divided in the following way:

Quadrant 1: top 30 countries;

Quadrant 2: $31^{\text {st }}-75^{\text {th }}$ position in the ranking;

Quadrant 3: $76^{\text {th }}-119^{\text {th }}$ position in the ranking;

Quadrant 4: the last 30 positions in the ranking.

Table 5. Some Indicators of Correlation (Pearson Coefficient) of Sub-Indices of the Legatum Prosperity Index for Four Groups of Countries according to the value of the Prosperity Index, 2016

\begin{tabular}{|l|c|c|c|c|}
\hline & Security - Health & Security - Social Capital & Security - Economic Quality & Social Capital - Health \\
\hline Quadrant 1 - High & $0.688^{* *}$ & 0.256 & $0.617 * *$ & 0.224 \\
\hline Quadrant 2 - Upper Middle & $0.452^{* *}$ & $-0.315^{*}$ & $0.375^{* *}$ & 0.024 \\
\hline Quadrant 3 - Lower Middle & $0.408^{* *}$ & $-0.400^{* *}$ & 0.101 & -0.231 \\
\hline Quadrant 4 - Lower & 0.036 & 0.091 & 0.217 & 0.174 \\
\hline
\end{tabular}

Note: the interpretation of the correlation coefficient is based on the level of the strength of the relationships:

$\mathrm{r}>0.01 \leq 0.29$ - weak positive relationship, $r>0.30 \leq 0.69$ - moderate positive relationship, $r>0.70 \leq 1.00$ - strong positive relationship, $r>-0.01 \leq-0.29$ - weak negative relationship, $r>-0.30 \leq-0.69$ - moderate negative relationship, $r>-0.70 \leq-1.00$ - strong negative relationship.

Source: compiled by the authors from the data provided by the research of the Legatum Institute

(Legatum Institute Foundation 2017)

The data presented in Table 5 show that the relationship between security and health is increasing as the countries are moving to the higher quadrants of the Prosperity Index. In the fourth quadrant, in general, the relationship between these sub-indices is not fixed by the Pearson Coefficient; this indicates that security is seriously influenced by other components of the Prosperity Index (especially by governance, ability of authorities to provide external security).

The Prosperity Index is interesting because the Legatum scientific institution has been tracking the Prosperity Index for several years, which allows to consider the dynamics of some separate sub-indices that reflect the economic quality, health, security and social capital. In 2016, Latvia was ranked $37^{\text {th }}$ among 149 countries, Ukraine $-107^{\text {th }}$. If to divide the given 149 countries into 4 sub-groups, Latvia is to be placed in the $2^{\text {nd }}$ subgroup (Upper Middle), Ukraine - in the $3^{\text {rd }}$ (Lower Middle). The correlation (the Pearson Coefficient) of the sub-indices related to the data available (149 countries) indicates a strong correlation among absolutely all sub-indices, which seems to reflect the legitimacy of including these sub-indices into the overall Prosperity Index. Latvia and Ukraine are in different quadrants and this is not surprising, because the level of social and economic development of Latvia is higher.

The correlation of social capital reflected by all data available is most evident through three sub-indices, which are very closely related: governance $(0.723)$, business environment $(0.680)$ and economic quality $(0.677)$. This circumstance can be interpreted as follows: in the most prosperous countries, an optimal combination of vertical and horizontal controls has been found. The state helps business and does not act like a racketeer, constantly increasing the tax burden on small and medium-sized businesses. In qualitative economy, an important place is taken by medium-sized enterprises. And all this together is, first of all, a positive result of social capital.

Latvia and Ukraine, which are under our detailed analysis, unfortunately, differ exactly in the common dominant problem - low volume of social capital. According to the sub-index of social capital, Latvia, which is placed in the $2^{\text {nd }}$ quadrant of the Prosperity Index, is ranked $94^{\text {th }}$, whereas Ukraine, placed in the $3^{\text {rd }}$ quadrant, has social capital characteristic for the countries of the $4^{\text {th }}$ quadrant - the $135^{\text {th }}$ position.

Having a low indicator of social capital, both Latvia and Ukraine cannot but be concerned about security issues. In Latvia (which is a country of NATO and the EU), this manifests itself as an issue of internal security, primarily as a number of issues related to the health of the population - in the ranking of sub-indices, "Health" 
is ranked $82^{\text {nd }}$, which corresponds to the third quadrant. In Ukraine, however, the issue of a low level of social capital is manifested both as an external component and as an internal one. Security takes the $134^{\text {th }}$ position, governance - the $128^{\text {th }}$ position, which corresponds to the $4^{\text {th }}$ quadrant. The sub-index "Health" is relatively low - ranked $111^{\text {th }}$ out of 149 .

In his book "Trust. The Social Virtues and the Creation of Prosperity", Francis Fukuyama extensively considers the role of social capital in the life of society (Fukuyama 1996). "Social capital", F. Fukuyama writes "is the capability that arises from the prevalence of trust in a society or in certain parts of it. It can be embodied in the smallest and most basic social group, the family, as well as the largest of all groups, the nation, and in all groups in between". Social capital differs from other forms of human capital insofar as it is usually created and transmitted through cultural mechanisms - through religion, traditions and historical customs that is why a rapid change in its volume is very problematic (Menshikov 2001).

The book by F. Fukuyama contains an original classification of societies, which is based on the prevalence of trust. He refers such seemingly diverse countries as Japan, the United States and Germany to the group of "societies with a high level of trust", while the equally diverse France, China and Taiwan, not to mention the countries of Eastern Europe and the former USSR, are defined as "societies with a low level of trust". The economic successes of the countries in the first group were, in his opinion, achieved in conditions, when the actions of the state merely complemented and coordinated the development of the society based on the principle of trust, and did not attempt to artificially create such a society. On the contrary, the societies with a low level of trust are marked by internal "desocialization", sometimes imperceptible at first glance; they bear the marks of family, clan or group isolation and are less capable of stable and natural development.

According to EUROSTAT data, in 2015, there were 109642 enterprises in Latvia (European Commission 2017 (1)). The consideration of the structure of Latvian enterprises offers an interesting picture: microenterprises (1-9 employees) accounted for 91.4\%, small enterprises (10-49 employees) - 7.1\%, medium enterprises (50249 employees) $-1.3 \%$, large enterprises ( 250 and more employees) $-0.2 \%$. However, the contribution of the latter to the national economy is about 40\% (European Commission 2015).

Fukuyama calls such a structure of enterprises saddle-shaped, where there are a large number of relatively small family companies on one side of the scale, and on the other - a small number of large state enterprises, and in the middle - almost nothing. The lack of trust between people who are not related by kinship, and, consequently, the weakness of voluntary associations, hinders (and in some cases does not allow) any large-scale capital-intensive production outside the state sector.

By analogy with the approach by Fukuyama, stratification of society also can be called saddle-shaped. On one side of the scale there are a large number of poor people, on the other - a statistically elusive share of the upper class, and in the middle - almost nothing. Of course, the volume of social capital in such a society cannot be a significant figure.

\section{Conclusions and Issues for Discussion}

The analysis provides a clearer vision of the model of strengthening the socialization of economy in terms of ensuring national security, with focus on economic security (Figure 3.). The weak realization of the socialization of the economy inevitably leads to an increase in the socioeconomic inequality of the population, when the main catalyst for this negative process can be, together with the economic inequality, other components of aggregate capital. For different countries, at different times these components of aggregate capital are purely specific. In some cases, the dominant threat is health capital, in others - human (vocational and educational). The proposed model uses the theory of aggregate capital as a methodology for analyzing the interrelationship between social economy and security; this model reflects the role of social capital as an important indicator of both inequality and stability and security. 


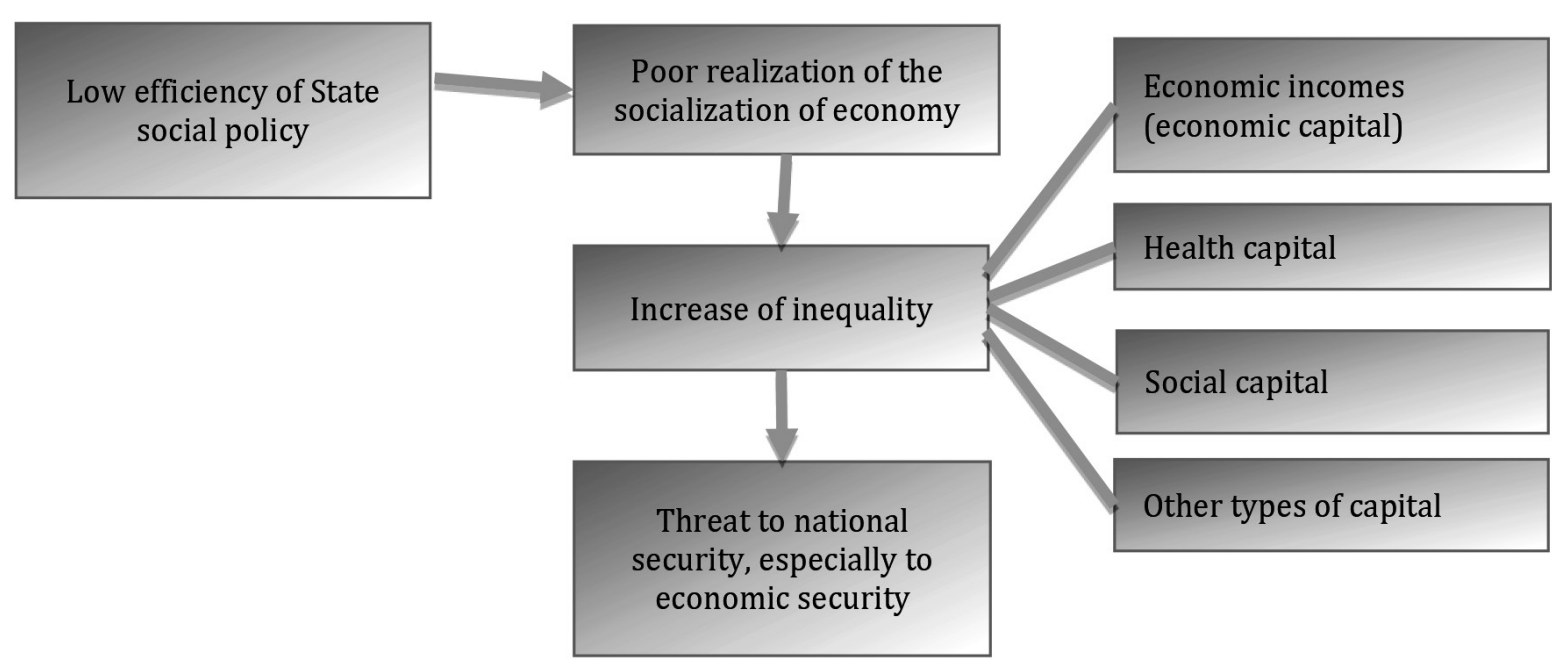

Figure 3. A conceptual diagram of the relationship among the elements of the subject of the research the role of socialization of economy in ensuring national security

Source: author's own work

In public life, we observe a noticeable presence of the elements of quasi-feudalism (neo-feudalism, electronic feudalism), which in the aspect of social stratification means a manifestation of class differentiation in a society. In our days, the economic mechanisms of the formation of such a society are associated with a specific dynamics of various economic processes. The economic bestseller by French economist Thomas Piketty, "Capital in the Twenty-First Century", is all about these things; it is devoted to economic inequality in Europe and the United States, tracing this phenomenon from the $18^{\text {th }}$ century (Piketty 2014). The central thesis of the book is that the concentration of wealth will increase, if the level of return on capital $(r)$ is higher than the level of economic growth $(g)$. Piketty argues that in the long term this will lead to a concentration of wealth and economic instability. In order to ensure conditions for equality and avoid falling of the lion' share of wealth under the control of an absolute minority, Piketty proposes to create a global system of progressive taxes on wealth.

As the analysis of the research data of the Legatum Institute shows, the country's prosperity depends on many internal and external factors of development. The internal factors of development, the vast majority of which are increasingly connected with the sociality of economy, ensuring national security become ever more important. The example of Latvia shows that the most notable decline in the Prosperity Index is related to the health of the population and the quality of health care. However, the way out from the health crisis cannot be found within only one social sector, without substantially increasing the social character of the entire economy, which requires a reduction in socioeconomic inequality, a genuine policy of the formation of a middle class.

Although the economic criterion remains as a basic one, the role of other class-forming criteria (which differently manifest themselves in countries with different levels of economic development, civilizational identity) becomes more and more noticeable. In the conditions of the formation of knowledge economy, cultural capital plays an increasingly noticeable role in the structure of the total capital of an employee. In the meantime, even higher education does not guarantee a high level of culture, new literacy, which presupposes an ever wider set of skills that go far beyond the sphere of language literacy (computer literacy, media literacy, financial literacy, etc.).

Curious enough, Oxfam, along with the publication of the data on inequality and fairly tough criticism of both corporations and governments, offers its own specific measures. The main ones are: 1. fighting tax evasion; 2. higher investments in the social sector, higher minimum wages. That is, the main fight should be with those who evade paying taxes. The Oxfam organization provides the following figures: $\$ 7$ trillion dollars - the money that goes to offshore organizations. If this had not happened, then governments would have received hundreds of billions of dollars to solve social programs. This moves us out from the field of global socio-economic problems into the field of a purely legal and, in fact, criminal sphere. To what extent is this most topical tax evasion 
problem solvable? How is it possible to make the monetary resources accumulated by fiscal services in the form of taxes in the state budget not only transparent and understandable, but desirable and approved for the taxpayers in the articles of the budget expenditures of a state?

The decline in the number and the reduction of the progressive role of the middle class are observable everywhere with the crisis of social state worsening and with the lack of economic and political resources for its real creation. Fragile attempts by parliaments and governments of some separate countries to impose taxes with a progressive scale, solidarity taxes, taxes on currency speculation and other measures of redistribution of aggregate incomes in favour of those who need social benefits, who seek to raise their status to the level of the middle class, are categorically rejected by representatives of large corporations and senior officials.

\section{References}

Andruseac, G. 2015. Economic security - new approaches in the context of globalization, CES Working Papers 7(2): 232-240. Available from: http://ceswp.uaic.ro/articles/CESWP2015_VII2_AND.pdf

Arhipov, A. 1994. Ekonomi4eskaya bezopasnost': ocenki, problemy, sposoby obespe4eniya (Economic security: assessments, problems, ways to ensure) v kn. A. Arhipov, A. Gorodeckii, B. Mihailov Voprosy ekonomiki 12: 36 - 44.

Avotiņš, V. 27.07.2017. Militārā mode politikā. [Military regime in politics] Nra.lv Available from: http://nra.lv/latvija/viktorsavotins/217084-militara-mode-politika.htm

Becker, D. S. 1964. Human Capital Theoretical and Empirical Analysis with Special Reference to Education, $3^{\text {rd }}$ ed., Chicago, London: The University of Chicago Press.

Bela, B. 2014. Latvia. Human Development Report 2012/2013. Sustainable Nation, Social and Political Research Institute of the University of Latvia, pp.112. Available from: http://www.szf.lu.lv/fileadmin/user_upload/szf_faili/Petnieciba/TAP_ENG_2013.pdf

Bourdieu, P. 1986. The forms of capital,in J. Richardson (Ed.)Handbook of Theory and Research for the Sociology of Education, New York, Greenwood, pp. 241-258.

Chernova, E.V. 2008. Vitalnyiy kapital v sisteme sostavlyayuschih chelovecheskogo kapitala (Vital capital in the system of human capital components). Nauchno-tehnicheskie vedomosti SPbGPU № 1, Ekonomicheskie nauki. (in Russian)

Clarkwest, A. 2008. Neo-Materialist Theory and the Temporal Relationship between Income Inequality and Longevity Change, Social Science and Medicine, pp.1871-1881. https://doi.org/10.1016/j.socscimed.2007.12.034

Cormac, R., 2014. Secret Intelligence and Economic Security: The Exploitation of a Critical Asset in an Increasingly Prominent Sphere, Intelligence and National Security 29(1): 99-121: http://dx.doi.org/10.1080/02684527.2012.748366

Dahlgren, G., Whitehead M., 2007. European strategies for tackling social inequities in health: Levelling up Part 2, World Health Organization. Available from: http://www.euro.who.int/_data/assets/pdf_file/0018/103824/E89384.pdf

Deaton, A. 2002. Policy implications of the gradient of health and wealth, Health Affairs 21(2): 13-30 https://doi.org/10.1377/ hlthaff.21.2.13

Elsevier, B.V. 2017. Scopus abstract and citation database. Available from: https://www.scopus.com/

European Commission 2015. GVA and persons employed (FTE) shares of large enterprises and SMEs in medium high and high technology manufacturing, 2012.png Available from: http://ec.europa.eu/eurostat/statistics-explained/index.php/File:GVA_and_persons_employed_(FTE)_shares_of_large_enterprises_and_SMEs_in_medium_high_and_high_technology_manufacturing,_2012.png

European Commision May 2017. Standart Eurobarometer 8 -Spring 2017. Public opinion in the European Union, First results, Available from: http://ec.europa.eu/commfrontoffice/publicopinion/index.cfm/Survey/index\#p=1\&instruments=STANDARD

European Commission 2017 (1). Annual enterprise statistics by size class for special aggregates of activities (NACE Rev. 2). Available from: http://appsso.eurostat.ec.europa.eu/nui/submitViewTableAction.do

European Commision 2017 (2). Government expenditure on social protection. Available from: http://ec.europa.eu/eurostat/statisticsexplained/index.php/Government_expenditure_on_social_protection

Fisher, I. 1906. The nature of capital and income, London: Macmillian \& Co., Ltd. Available from: https://archive.org/details/natureofcapitali00fishuoft 
Fogel, R.W. 2003. Secular Trends in Physiological Capital: Implications for Equity in Health Care, Perspectives in Biology and Medicine, Summer 46 (3 Suppl): S24-S38.

Fukuyama, F. 1996. Trust. The Social Virtues and the Creation of Prosperity, N.Y., free Press.

Galama, T.J. 2013. Health Inequalities through the Lens of Health Capital Theory: Issues, Solutions, and Future Directions. https://doi. org/10.1108/S1049-2585(2013)0000021013

Gasparènienè, L.; Remeikienè, R.; Sadeckas, A.; Ginevičius, R. 2016. Level and sectors of digital shadow economy: the case of Lithuania, Entrepreneurship and Sustainability Issues 4(2): 183-197 https://doi.org/10.9770/jesi.2016.4.2(6)

Geyec, V. M., Kizim, M. O., Klebanova, T. S., Chernyak O. I. ta in. 2006. Modelyuvannya ekonomi4noï bezpeki: derjava, region, pidpriemstvo (Modeling of economic security: state, region, enterprise). monografiya, VD «Injek», 240 s. (in Ukrainian)

Grossman, M. 1972. On the Concept of Health Capital and the Demand for Health, The Journal of Political Economy, Vol. 80, No. 2. pp. 223-255. Available from: http://economics.sas.upenn.edu/ hfang/teaching/socialinsurance/readings/Grossman $72 \% 283.1 \% 29$. pdf

Dirzytè, A.; Rakauskienè, O. G.; Servetkienè, V. 2017. Evaluation of resilience impact on socio-economic inequality, Entrepreneurship and Sustainability Issues 4(4): 489-501. https://doi.org/10.9770/jesi.2017.4.4(7)

Hall, R.E., Jones, C.E. 2007. The value of life and the rise in health spending, Quarterly Journal of Economics 122: 39-72. Available from: https://web.stanford.edu/ chadj/HallJones2007.pdf

Holikov, I. 2014. Principles of economic security, ECONOMIC ANNALS-XXI 9-10 (2): 8-11.

ICRC 2017. What is Economic Security? Available from: https://www.icrc.org/en/document/introduction-economic-security

Jackson, T., Victor, A.P. 2015. Does slow growth lead to rising inequality? A stock- flow consistent exploration of the 'Piketty hypothesis',PASSAGE Working Paper 14/02. Guildford: University of Surrey. DOI: https://doi.org/10.1016/j.ecolecon.2015.03.019

Krugman, P. R. 2007. The Conscience of a Liberal. W.W. Norton \& Co., 352 p.

Lankauskienė, T.; Tvaronavičienè, M. 2012. Security and sustainable development: approaches and dimensions in the globalization context, Journal of Security \& Sustainability Issues 1(4): 287-297. https://doi.org/109770/jssi.2012.1.4(5)

Legatum Institute Foundation 2017. The Legatum Prosperity Index 2016 ranking table http://www.prosperity.com/rankings

Legatum Institute 2016. The Legatum Prosperity Index 2016. Prosperity to Life. Tenth edition. Available from: http://www.prosperity. com/download_file/view_inline/2857 p.14

Lloyd, W., Meeker, M., Eells, K. 1949. Social class in America : a manual of procedure for the measurement of social status. Chicago: Science Research Ass. Inc., 274 p.

Menshikov, V. 2001. Sotsialnyiy kapital Latvii: sostoyanie i noveyshie tendentsii (Social capital of Latvia: current status and latest trends), Starptautiskās konferences „Ekonomisko un sociālo attiecību transformācija: procesi, tendences, rezultāti” rakstu krājums, Biznesa augstskola Turība” SIA, Rīga. str. 258-264

Menshikov, V. 2002. Neofeodalizm protiv sotsialnogo gosudarstva. Sotsialno-ekonomicheskie problemyi v postsotsialisticheskom prostranstve (Neo-feudalism against the social state. Socio-economic problems in the post-socialist space), ch.1. Moskva: Akademiya truda i sotsialnyih otnosheniy, str.98-105.

Menshikov, V. 2008. Capital in Sociological Aspect: Theoretical Bases of Investigation and Operational Parameters, Kultura a Rynek, Lublin: Wydawnictwo KUL, pp.180-186.

Menshikov, V. 2011. Human capital in the structure of total capital of a personality: sociological aspect, Philosophy. Sociology, T. 22, No.2. Vilnius, Lithuanian Academy of Science, pp.149-160.

Menshikov, V. 2016. Experience of research of social classes in Latvia, Philosophy. Sociology 27(2). Lithuanian Academy of Sciences.

Menshikov, V., Vanags, E., Volkova, O. 2013. Sociological interpretations of data on the aggregate capital of regional population (work experience abroad, relation to labour migration, factors of life success), Philosophy. Sociology 24(4) Lietuvos mokslų akademija: 226-236

Meņšikovs, V. 2013. Kopkapitāls, tā struktūra un saikne ar darba migrāciju (uz Latgales piemēra), Daugavpils Universitātes Sociālo zinātņu fakultātes starptautisko zinātnisko konferenču rakstu krajums.1 daļa. Sociologijas aktualitātes, Daugavpils Universitāte, 
akadēmiskais apgāds „Saule” [The authorized capital, its structure and connection with labor migration (on the example of Latgale ), Article of international scientific researches of faculty of social sciences of Daugavpilssky University. Part 1. The relevance of sociology, Daugavpils University, Academic Publishing House "Saule". 19-40 lpp. Available from: https://du.lv/wp-content/ uploads/2013/10/2Menshikov.pdf

Meņšikovs, V. 2004. Cilvēkdrošība Latvijā: socioloǵiskais aspekts [Human Security in Latvia: Sociological Aspect] (1), Sociālo Zinātņu Vēstnesis [Journal of Social Science] 1: 30-60.

Meņšikovs, V. 2005. Cilvēkdrošība Latvijā: sociologiiskais aspekts (2) [Human Security in Latvia: Sociological Aspect], Sociālo Zinātņu Véstnesis [Journal of Social Science] 1(2): 24-50.

Müller-Armack, A. 1946. Wirtschaftslenkung und Marktwirtschaft [Economic governance and market economy]. pp. 19-170

Müller-Armack, A. 1966. Wirtschaftsordnung und Wirtschaftspolitik. Studien und Konzepte zur Sozialen Marktwirtschaft und zur Europäischen Integration [Economic order and economic policy. Studies and concepts on the social market economy and European integration], Freiburg, 469 p. -p. 245

Nelson, R. 2009. A NEW (net economic welfare) measure of economic health. Available from: http://www.edn.com/electronics-blogs/ taking-the-measure/4377396/A-NEW-net-economic-welfare-measure-of-economic-health

Oxfam 2017. Just 8 men own same wealth as half the world. Available from: https://www.oxfam.org/en/pressroom/pressreleases/2017-01-16/just-8-men-own-same-wealth-half-world

Ozoliņa, Ž. (red.) 2012. Cilvēkdrošība Latvijā un pasaulē: no idejas līdz praksei,,,Zinātne” Publishers, p. 463.

Ozoliņa, Ž. (red.) 2016. Societal Security: Inclusion-Exclusion Dilemma. A portrait of Russian-speaking community in Latvia, „Zinātne” Publishers, p.223

Panfiluk, E.; Szymańska, E. 2017. The measurement of the innovativeness of health tourism services using an adequacy matrix title of the article, Entrepreneurship and Sustainability Issues 4(4): 400-420. https://doi.org/10.9770/jesi.2017.4.4(1)

Parsons, T. 1937. Structure of Social Action, N.Y., London, Mc Graw Hill.

Petty, W. 1899 [1691]. Verbum sapienti. Reprinted in The economic writings of Sir William Petty, Vol. 1. Cambridge: Cambridge University Press. Available from: http://files.libertyfund.org/files/1677/0605-01_Bk.pdf

Piketty, T. 2014. Capital in the Twenty-First Century, Harvard University Press.

Predborskiy, V. A. 2005. Detinizatsiya ekonomiki u konteksti transformatsiynih protsesiv: Pitannya teoriï i metodologiï (Detonization of the economy in the context of transformational processes: The questions of theory and methodology): monografiya, K.: Kondor, 614 s. (in Ukrainian)

Raudeliūnienè, J.; Tvaronavičienė, M.; Dzemyda, I. 2014. Towards economic security and sustainability: key success factors of sustainable entrepreneurship in conditions of global economy, Journal of Security and Sustainability Issues, 3(4), pp. 71-79. https://doi. org/10.9770/jssi.2014.3.4(7)

Restakis, J. 2007. Defining the Social Economy: The BC Contex. Available from: http://www.msvu.ca/socialeconomyatlantic/pdfs/ DefiningSocialEconomy_FnlJan1906.pdf

Ringach, N. O. 2009. Gromadske zdorov'ya yak chinnik natsionalnoï bezpeki (Public health as a factor of national security). Monografiya, K.: NADU, 296 s. (in Ukrainian)

Rozanov, A. A., Shapiro, A.V. 1994. Bezopasnost': podhodyi zapada (Security: approaches of the West), Minsk: Universitetskae. 125 s. (in Russian)

Runcis, A. 1999. Latvia towards Europe: internal security issues. (Final Report, NATO). Riga. - 50 p.

Available from: https://www.nato.int/acad/fellow/97-99/runcis.pdf

Rus.delfi.lv 2013. U bolshinstva latviytsev - problemyi s semeynyim byudjetom (The majority of Latvians have problems with the family budget). Available from: http://rus.delfi.lv/archive/print.php?id=43158892

Sardak, S., Bilska, O., Simakhova, A. 2017. Potential of economy socialisation in the context of globalization, EconomicAnnals-XXI 164(3-4): 4-8. DOI: https://doi.org/10.21003/ea.V164-01

Simakhova, A.O. 2016. Analysis of the Foreign Economic Factors Impact on the Welfare of Ukrainians in the Conditions of the World 
Integration Processes, Marketing and Management of Innovations 3: 263-271.

Standing, G. 2011. The Precariat: The New Dangerous Class, London and New York: Bloomsbury Academic.

Slyusareva, E. 31.05.2017. Do poslednego bolnogo? Valdis Keris - o pozore latviyskogo zdravoohraneniya (Until the last patient? Valdis Karis - about the shame of Latvian health). Available from: http://www.press.lv/post/do-poslednego-bolnogo-valdis-keris-opozore-latvijskogo-zdravoohraneniya/

Stukalo, N. 2006. Evaluating the State of Financial Globalization: Ukraine's Specific Features, International Economic Policy, 4, pp. 84-102. Available from: http://iepjournal.com/journals_eng/4/2006_1_Stukalo_eng.pdf

Stukalo, N. V., Simakhova, A. O. 2017. Social economy models in market conditions, University Economic Bulletin 34(1): $214-220$.

The World Bank 2005. World development report 2006. Equity and Development. Oxford University Press. Available from: http://documents.worldbank.org/curated/en/435331468127174418/pdf/322040World0Development0Report02006.pdf

Tumalavičius, V. 2017. Legal regulatory enhancement of society's security under globalisation: the example of Lithuania. Doctoral Thesis. Daugavpils University.

Tumalavičius, V., Veikša, I., Načisčionis, J., Zahars, V., Drascovic, V. 2017. Issues of State and Society Security (Part I): Ensuring Public Security in the Fight against Crime, Journal of Security and Sustainability Issues 6 (3); 401-418. https://doi.org/109770/jssi.2017.6.3(7)

UN General Assembly 1979. Health as an integral part of development. UN resolution A/RES/34/58 Available from: http://www. un.org/ru/ga/34/docs/34res.shtml

UNDP Latvia 2003. Human Development Report 2002/2003 Human Security, Riga.

UNDP 2016.Human Development Report 2016. Human Development for Everyone. New York, USA; Canada: Lowe-Martin Group.

Valeriu, I. F., Diamescu, M. A. 2010. Some Opinions on the Relation between Security Economy and Economic Security. The National Institute for Economic Research, The Romanian Academy, Bucharest, Romania. pp. 129-159.

Wagstaff, A., Culyer, A. J. 2012. Four decades of health economics trough a bibliometric lens, Journal of Health Economics 31: 406439. https://doi.org/10.1016/j.jhealeco.2012.03.002

Wilkinson, R., Pickett, K. 2009. The Spirit Level: Why More Equal Societies Almost Always Do Better, London: Allen Lane, p.400.

World Health Organization 1990. Targets for Health for All, Copenhagen, WHO Regional Office for Europe, Available from: http:// www.euro.who.int/_data/assets/pdf_file/0006/109779/WA_540_GA1_85TA.pdf

\section{About contributors:}

Dr. sc. soc. Vladimir MENSHIKOV is Professor, Head of the Centre of Social Research in Daugavpils University. Research interests: sociology of security; regional development; capital theory. He has status of experts of the Latvian Council of Science in the fields of economics and sociology.

Mg. oec. Olga VOLKOVA is doctoral student in regional economics, scientific assistant at the Institute of Humanities and Social Sciences of Daugavpils University. Research interests: socio-economic inequalities, capital theory, public health.

Nataliia STUKALO is Doctor of Economic Sciences, Professor, Dean of International Economics Faculty of Oles Honchar Dnipro National University; Principal Editor of World Economy and International Economics Relations Journal. Research interests: globalization and its impact on national economies and financial systems, substantial development and the tools of its implementing, European Union economic, financial and currency policy and problems of European integration of Ukraine.

Anastasiia SIMAKHOVA is the Professor Assistant of Department of Economics and Management of National Economy of Oles Honchar Dnipro National University, Candidate of Economic Science. Research interests: social economy models, global economy social metrics, national economy development, socialization, globalization, economic and social development. 